\title{
Dosage de la cocaïne et de ses métabolites dans les cheveux, la salive et les urines
}

\section{Analysis of cocaine and metabolites in hair, oral fluid and urine}

\begin{abstract}
Christine MOORE ${ }^{(1) *}$, Michaël FELDMAN ${ }^{(2)}$, Edward HARRISON ${ }^{(2)}$, Dwain IRVAN ${ }^{(2)}$, David KUNTZ ${ }^{(2)}$, Wayne ROSS ${ }^{(3)}$, Nadia GIORGI ${ }^{(3)}$, Alpana AGRAWAL ${ }^{(1)}$, Sumandeep RANA ${ }^{(1)}$, Michaël VINCENT ${ }^{(1)}$, James SOARES $^{(1)}$
\end{abstract}

(1) Immunalysis Corporation, 829 Towne Center Drive, Pomona, CA 91767, USA (2) LabOne, Salt Lake City, Hayes Building, Unit C, 2282 South Presidents Drive, West Valley City, UT 84120, USA (3) Redwood Toxicology Laboratory, 3650 Westwind Boulevard, Santa Rosa, CA 95403, USA

*Corresponding Author: Christine MOORE PhD, Immunalysis Corporation, 829 Towne Center Drive, Pomona, CA 91767, USA - Tel: 1-909 4820840 - Fax: 1-909 4820850 - E-mail: cmoore@immunalysis.com

\section{$R E^{S} S M{ }^{E}$}

Des révisions proposées aux directives fédérales incluant l'utilisation potentielle des cheveux, de la salive ainsi que des urines pour le dépistage des conduites addictives en entreprise ont été publiées en 2004. Cette étude a été conçue pour déterminer le taux de positivité de différents types d'échantillons, dans une population toxicomane et dans une autre niant sa consommation de cocaïne. Cette étude a été menée sur 200 sujets, la moitié admettant une consommation de cocaïne, l'autre moitié la niant. Chaque sujet a donné un échantillon d'urine, de salive et de cheveux prélevés au moment de l'entrevue. Pour chaque sujet, des informations sur leur consommation de stupéfiants, incluant le moment de la dernière prise et la fréquence de consommation, leur appartenance ethnique, leur âge, leur sexe et la couleur de leurs cheveux ont été enregistrés. Les échantillons ont été analysés pour la cocaïne et/ou ses métabolites selon la matrice. Les résultats sont présentés ci-dessous.

Les cheveux ont identifié le plus grand nombre de toxico-

\section{SUMMARY}

Proposed revisions to the Federal guidelines, which include the potential use of hair and oral fluid, as well as urine, for workplace drug testing were published in 2004. This study was designed to determine the positivity rate in various specimen types, both in a drug using population and a population denying cocaine use. The study enrolled 200 subjects, half of whom admitted to cocaine use, half who did not. Each subject provided a urine sample, an oral fluid and a hair specimen taken from the head at the time of interview. Information on drug use, including time of last use, frequency of use, ethnicity, age, sex and hair color were recorded for each subject. The specimens were analyzed for cocaine and/or its metabolites depending on the matrix and the data is presented.

Hair identified the highest number of drug users in both the admitted using population and those who denied use. Oral fluid and urine gave similar detection rates in both populations, with oral fluid slightly better in the self-reported non- 
manes dans les deux populations. La salive et les urines ont donné des taux de détection similaires dans les deux populations, avec une meilleure détection dans la salive pour la population se disant saine et une meilleure détection dans les urines pour la population s'admettant consommatrice de cocaüne.

C'est la première étude où des cheveux, de la salive et des urines ont été collectés simultanément sur une population toxicomane. Le cheveu est la matrice la plus appropriée pour identifier des consonmateurs de cocaüne.

\section{Introduction}

The purpose of our study was to determine which of the three matrices - hair, oral fluid or urine, identified the highest number of drug users in a population admitting to cocaine use, and in a population denying drug use. Proposed revisions to the Federal guidelines, which include the potential use of hair, sweat and oral fluid for workplace drug testing were published in the Federal Register in 2004 (1).

In our study, a hair was considered a positive if it contained at least $500 \mathrm{pg} / \mathrm{mg}$ of cocaine and at least 25 $\mathrm{pg} / \mathrm{mg}$ of benzoylecgonine; or at least $50 \mathrm{pg} / \mathrm{mg}$ of cocaethylene or norcocaine, following a positive screening result. An oral fluid specimen was considered positive when at least $8 \mathrm{ng} / \mathrm{mL}$ of cocaine or benzoylecgonine was present following a screen positive result of greater than $20 \mathrm{ng} / \mathrm{mL}$. A cumulative result, for example $4 \mathrm{ng} / \mathrm{mL}$ of cocaine and $4 \mathrm{ng} / \mathrm{mL}$ of benzoylecgonine was not considered positive.

\section{Hair}

Human hair grows at approximately $1-1.3 \mathrm{~cm}$ per month, and has been measured using various biomarkers (2). Hair, due to its growth rate and stability, offers a much longer history of drug exposure than any other matrix. Hair has been increasingly chosen as a workplace test specimen, since, in contrast to urine, the collection is observed, and the possibility of adulteration or substitution of the specimens is reduced. There are many publications regarding the incorporation of cocaine into hair (3-5). Cocaine itself is preferentially incorporated into the hair shaft, although several of its metabolites, including benzoylecgonine, norcocaine and cocaethylene have been detected and analyzed using well established procedures $(6,7)$. For the screening of drugs in hair, both methanol and aqueous extraction procedures have been published (8); and for confirmatory analysis, gas chromatography with mass spectrometric detection is the preferred laboratory procedure (9), although LC/MS and LC/MS/MS are being increasingly employed in testing laboratories. using population, and urine slightly better in the self-reported cocaine user population.

This is the first study where hair; oral fluid and urine were collected simultaneously from a drug using population. Hair is the most likely matrix to identify cocaine users.

\section{Oral Fluid}

Oral fluid is a useful specimen for the determination of recent drug use, and in some cases drugs detected may be directly related to human performance. The main advantage of oral fluid over urine for workplace testing is that the collection of the specimen is observed, circumventing the additional expense of testing for adulterants in the laboratory (10). There are several review papers regarding the analysis of drugs in oral fluid (11), and there are a number of published articles specific to the disposition of cocaine in plasma and saliva following administration $(12,13)$. Generally, cocaine and its metabolite benzoylecgonine are the predominant drugs detected in saliva. Oral fluid is an excellent specimen for analysis when recent drug use is suspected, such as in "for cause" or roadside testing.

\section{Urine}

Urine has been the accepted specimen for Workplace Drug Testing for many years, however, problems with adulteration and substitution of samples, due to collection not being observed, have prompted the need for other, or "alternative" matrices. These problems caused laboratories to increase their workload by testing for oxidants, nitrites or other adulterants $(14,15)$. Urine is the most widely tested substance, and generally contains higher levels of drug metabolites than the other matrices. It is useful for random testing, and in probation and parole settings.

\section{Materials and Methods}

\section{Subjects}

The study enrolled 200 subjects, from the Drug and Alcohol Recovery Team (DART) in Fullerton, Orange County, Southern California. The study was approved under Immunalysis Institutional Review Board IRB \# 2004-05-001. All subjects participating in the study were made aware of the purpose of the study, and signed a consent form. While information on drug use, including time of last use, frequency of use, ethnicity, age, sex and hair color were recorded for each subject, 
names, addresses or other identifying information was not collected on the interview sheet. Complete anonymity was established during the sample collection and laboratory testing procedures.

One hundred of the enrolled subjects admitted cocaine use in the recent past, the others denied drug use. Each subject provided a urine sample, an oral fluid and a hair specimen taken from the head at the time of interview. Of the 100 volunteers who admitted cocaine use, $19 \%$ were females and $81 \%$ were male. $60 \%$ of the subjects were black, $23 \%$ were white, $11 \%$ were Hispanic and $6 \%$ described themselves as "other". The subjects ranged in age from 21 to 65 years old, and frequency of use ranged from daily to once a month.

Of the 100 volunteers who did not admit to cocaine use, $28 \%$ were female and $72 \%$ were male. $53 \%$ were white; $21 \%$ black; $14 \%$ considered themselves "other" and $12 \%$ were Hispanic. The age range was the same as for the drug users.

\section{Experimental}

Hair and oral fluid screening kits were obtained from Immunalysis Corporation (Pomona, CA). The Cocaine Direct ELISA Kit (Catalog \# 229-0480) was used for screening the hair specimens and the Cocaine and Benzoylecgonine Direct ELISA Kit (Catalog \# 2120480) was used for screening oral fluid specimens. Both were used according to the manufacturer's package insert instructions. For confirmatory procedures, deuterated $\mathrm{d}_{3}$-cocaine, $\mathrm{d}_{3}$-benzoylecgonine (BZE) and $\mathrm{d}_{3}$-cocaethylene internal standards as well as unlabelled drug standards were obtained from Cerrilliant (Round Rock, TX). Solid phase mixed mode cation exchange - hydrophobic phase extraction columns (CSDAU020) were obtained from United Chemical Technologies Inc. (Bristol, PA). Clin-II $35 \mathrm{mg}$ mixed mode, cation exchange - hydrophobic phase extraction columns were purchased from SPEWare (San Pedro, CA). The derivatizing agents pentafluoropropanol (PFPOH), pentafluoropropionic anhydride (PFPA) heptafluorobutyric anhydride (HFBA) were obtained from Pierce Chemical Co. (Rockford, IL). Trifluoroethanol was obtained from Aldrich (Milwaukee, WI). All solvents were HPLC grade or better, and all chemicals were ACS grade.

\section{Hair}

\section{Screening Assay}

The hair was cut into small segments (3-5 mm), and an aliquot of $10 \mathrm{mg}$ was weighed. The hair was washed briefly with methanol ( $2 \mathrm{~mL} / 10 \mathrm{~min})$, the solvent was decanted and the hair was allowed to dry. To the hairs, $0.025 \mathrm{M}$ monobasic phosphate buffer with $0.1 \%$ bovine serum albumin (BSA) (pH 2.7, $0.5 \mathrm{~mL}$ ) was added, the tubes were capped and incubated at $60^{\circ} \mathrm{C}$ for one hour. $0.5 \mathrm{M}$ dibasic phosphate buffer ( $\mathrm{pH} 9.0 ; 50 \mu \mathrm{L}$ ) was added to neutralize the acid environment and the liquids were transferred to corresponding clean glass tubes. All specimens, calibrators and controls were then diluted $1: 5$ by adding $400 \mu \mathrm{L}$ of phosphate buffer saline (PBS with $0.1 \%$ BSA, pH 7.0) to $100 \mu \mathrm{L}$ of extract. An aliquot of the diluted hair extract $(20 \mu \mathrm{L})$, along with Horseradish peroxidase enzyme labeled cocaine derivative $(100 \mu \mathrm{L})$ was added to the individual micro-plate well coated with a cocaine specific antibody. After incubation (60 min, room temperature), the micro-plate wells were washed with deionized water $(6 \times 300 \mu \mathrm{L})$. Tetramethyl benzidine (TMB, $100 \mu \mathrm{L}$ ) was added to each well and the plate incubated in the dark for 30 minutes. The reaction was stopped using $1 \mathrm{~N}$ hydrochloric acid $(100 \mu \mathrm{L})$ and the plate read at $450 \mathrm{~nm}$ with a reference wavelength of $620 \mathrm{~nm}$.

In order to determine the limit of detection (LOD) of the assay, 16 replicates of hair specimens spiked with low levels of cocaine were analyzed using the ELISA procedure described. The minimum detectable concentration of cocaine was determined to be $15 \mathrm{pg} / \mathrm{mg}$. The intra-day precision of the assay was determined by spiking 16 replicates of drug free hair at $50 \%, 100 \%$, $150 \%$ and $200 \%$ of the recommended screening cut-off concentration for cocaine. At $500 \mathrm{pg} / \mathrm{mg}$ the coefficient of variation (CV) of the assay was $3.04 \%$. Inter-day precision was determined by the analysis of eight replicates at each of the concentrations on three different days. The coefficient of variation at $500 \mathrm{pg} / \mathrm{mg}$ was $4.74 \%$. The specificity of the kit was determined by analyzing structurally similar drugs to cocaine in the ELISA format. The percentage cross-reactivity with respect to cocaine response at $500 \mathrm{pg} / \mathrm{mg}$ was $9 \%$ for benzoylecgonine, $133 \%$ for cocaethylene and $5.5 \%$ for $m$-hydroxybenzoylecgonine. Benzoylecgonine isopropyl ester displayed the highest degree of cross-reactivity at $200 \%$. Other cocaine related compounds, e.g. norcocaine, ecgonine, ecgonine methyl ester were less than $5 \%$ cross-reactive to the antibody.

\section{Confirmation Assay}

Presumptive positive samples identified using the screening assay were carried forward to confirmation using gas chromatography-mass spectrometry (GC/MS) operating in electron impact mode. A separate aliquot of hair was weighed out $(2-10 \mathrm{mg}$, depending on the numerical screening result) and methanol $(1 \mathrm{~mL})$ was added. The samples were incubated for 1 5 minutes at room temperature, and the methanol was discarded. The internal standard solution containing $\mathrm{d}_{3}-$ cocaine, $\mathrm{d}_{3}$-benzoylecgonine (BZE) and $\mathrm{d}_{3}$-cocaethylene was added to the hair samples to give concentrations of 500,50 and $50 \mathrm{pg} / \mathrm{mg}$ respectively. 
Low controls $(200 \mathrm{pg} / \mathrm{mg}$, for cocaine, $20 \mathrm{pg} / \mathrm{mg}$ for metabolites), a cut-off calibrator, and high controls (625 pg/mg for cocaine, $62.5 \mathrm{pg} / \mathrm{mg}$ for metabolites), as well as a hydrolysis control at $5000 \mathrm{pg} / \mathrm{mg}$ of cocaine only, in order to monitor any cocaine conversion to BZE were included in every batch. A separate internal standard for norcocaine was not included since the retention time of cocaethylene and norcocaine were so close. The norcocaine was quantified using deuterated cocaethylene as the internal standard. An interference control comprising bupivicaine $(10 \mu \mathrm{g} / \mathrm{mL})$, mepivicaine, etidiocaine, prilociane, lidocaine, ephedrine and pseudoephedrine $(5 \mu \mathrm{g} / \mathrm{mL})$ was also included to ensure the reliability of peak identification.

$0.1 \mathrm{M}$ hydrochloric acid $(1 \mathrm{~mL})$ was added to each of the washed hair specimens, and the tubes were heated at $75^{\circ} \mathrm{C}$ for two hours. The acid was decanted into clean glass tubes, $0.1 \mathrm{M}$ phosphate buffer ( $\mathrm{pH} 6.0$, $1 \mathrm{~mL}$ ) and $0.1 \mathrm{M}$ sodium hydroxide was added until the $\mathrm{pH}$ was $6.0-6.5$.

Solid-phase mixed mode cation exchange/hydrophobic extraction columns were placed into a vacuum manifold. Each column was conditioned with methylene chloride: isopropanol: ammonium hydroxide (80:20:1.8; $2 \mathrm{~mL}$ ), methanol ( $3 \mathrm{~mL}$ ) and $0.1 \mathrm{M}$ phosphate buffer ( $\mathrm{pH} 6.0 ; 2 \mathrm{~mL}$ ). The samples were allowed to flow through the columns without vacuum. The columns were washed with deionized water $(2 \mathrm{~mL})$, $0.1 \mathrm{M}$ hydrochloric acid $(2 \mathrm{~mL})$ and methanol $(3 \mathrm{~mL})$, then allowed to dry at 15 psi for $5 \mathrm{~min}$. The drugs were finally eluted using fresh methylene chloride : isopropanol : ammonium hydroxide $(80: 20: 1.8 ; 2 \mathrm{~mL})$ and the extracts were evaporated to dryness under nitrogen $\left(15 \mathrm{psi}, 60^{\circ} \mathrm{C}\right)$. Pentafluoropropanol (PFPOH; $\left.50 \mu \mathrm{L}\right)$ and pentafluoropropionic anhydride (PFPA; $50 \mu \mathrm{L}$ ) were added. The tubes were capped and heated $\left(75^{\circ} \mathrm{C}\right.$, $15 \mathrm{~min}$ ). The extracts were again evaporated to dryness and reconstituted in pyridine/ethyl acetate (1:4) $(50 \mu \mathrm{L})$. The extracts were transferred to auto-sampler vials for $\mathrm{GC} / \mathrm{MS}$ analysis.

\section{Analytical Conditions (GC/MS)}

An Agilent Technologies 6890 gas chromatograph coupled to a 5973 mass selective detector (MSD) operating in electron impact mode was used for analysis (GC/MS). The gas chromatographic column was 5\% phenyl-95\% methyl silicone DB-5, $0.20 \mathrm{~mm}$ ID, $0.33 \mu \mathrm{m}$ film thickness, $12 \mathrm{~m}$ length (J \& W Scientific, an Agilent Company, Palo Alto, CA) and the injection temperature was $250^{\circ} \mathrm{C}$. The injection mode was splitless. The oven was programmed from $80^{\circ} \mathrm{C}$ for 30 seconds; ramped at $30^{\circ} \mathrm{C} / \mathrm{min}$ to $220^{\circ} \mathrm{C}$; then ramped at $10^{\circ} \mathrm{C} / \mathrm{min}$ to $240^{\circ} \mathrm{C}$, and finally at $50^{\circ} \mathrm{C} / \mathrm{min}$ to $300^{\circ} \mathrm{C}$, where it remained for two minutes. The transfer line was held at $280^{\circ} \mathrm{C}$. The ions monitored were 185 and 306 for deuterated cocaine; 182,303 and 272 for cocaine; 424 and 303 for deuterated benzoylecgonine; 421, 316 and 300 for benzoylecgonine; 272, 212 and 196 for cocaethylene; 194, 313 and 214 for norcocaine.

A sample was not considered positive, unless it contained at least $500 \mathrm{pg} / \mathrm{mg}$ of cocaine, and also contained benzoylecgonine at a level greater than $5 \%$ of the cocaine value. The presence of either norcocaine or cocaethylene at a concentration greater than $50 \mathrm{pg} / \mathrm{mg}$ as well as $500 \mathrm{pg} / \mathrm{mg}$ of cocaine was also considered a positive result.

\section{Oral Fluid}

The oral fluid specimens were collected using a Quantisat collection device (Immunalysis, Pomona CA). When the absorbent collection pad had absorbed $1 \mathrm{~mL}$ of neat oral fluid (+-10\%), a blue dye was visible in the indicator window on the plastic stem of the collection pad. The pad was placed in a polypropylene transport tube containing $3 \mathrm{~mL}$ of extraction buffer solution, capped and taken to the laboratory.

\section{Screening Assay}

The Cocaine and Benzoylecgonine Direct ELISA Kit (Immunalysis Corporation, Pomona, CA) was used for screening the oral fluid specimens. In order to determine the limit of detection (LOD) of the assay, 16 replicates of negative and low level cocaine oral fluid specimens were analyzed using the ELISA procedure described. The minimum detectable concentration of benzoylecgonine was determined to be $1.25 \mathrm{ng} / \mathrm{mL}$ of neat oral fluid equivalents. The intra-day precision of the assay was determined by spiking 16 replicates of drug free oral fluid at $50 \%, 100 \%, 150 \%$ and $200 \%$ of the recommended screening cut-off concentration. At 20 $\mathrm{ng} / \mathrm{mL}$, the coefficient of variation (CV) of the assay was $9.27 \%$. Inter-day precision was determined by the analysis of eight replicates at each of the five concentrations on three different days. The coefficient of variation at $20 \mathrm{ng} / \mathrm{mL}$ was $5.15 \%$. The specificity of the kit was determined by analyzing structurally similar drugs in the ELISA format. The percentage cross-reactivity with respect to benzoylecgonine at $20 \mathrm{ng} / \mathrm{mL}$ was $80 \%$ for cocaine and cocaethylene. Other benzoylecgonine related compounds, e.g. norcocaine, ecgonine, ecgonine methyl ester were less than $10 \%$ cross-reactive to the antibody.

An aliquot of the diluted oral fluid specimen $(40 \mu \mathrm{L})$ obtained from the Quantisal collection system was added to the individual micro-plate wells, and the assay was performed as previously described according to the manufacturer's package insert. Presumptive positive specimens were analyzed for cocaine and benzoylecgonine. 


\section{Confirmation Assay}

Oral fluid + buffer $(1 \mathrm{~mL})$ was removed from the Quantisal collector. Deuterated internal standard was added to the calibrator and controls giving a concentration of $16 \mathrm{ng} / \mathrm{mL}$, or an equivalent concentration to $4 \mathrm{ng} / \mathrm{mL}$ of diluted sample. Controls at concentrations of $4 \mathrm{ng} / \mathrm{mL}$ and $20 \mathrm{ng} / \mathrm{mL}$ were included in each confirmation batch. $0.1 \mathrm{M}$ potassium phosphate buffer $(\mathrm{pH}$ $6.0,1 \mathrm{~mL}$ ) was added and the sample was mixed. Solid phase extraction columns (Clin-II, SPEWare) were conditioned with methanol ( $2 \mathrm{~mL})$ and $0.1 \mathrm{M}$ phosphate buffer $(\mathrm{pH} 6.0 ; 2 \mathrm{~mL})$. The samples were added and the columns washed with deionized water $(2 \mathrm{~mL})$; $0.1 \mathrm{M}$ hydrochloric acid $(2 \mathrm{~mL})$; methanol $(3 \mathrm{~mL})$ and ethyl acetate $(3 \mathrm{~mL})$. Glass collection tubes were placed into the sample rack and the drugs eluted with methylene chloride: isopropanol: ammonium hydroxide $(78: 20: 2 \mathrm{v} / \mathrm{v}, 3 \mathrm{~mL})$. The samples were evaporated to dryness under nitrogen.

Methylene chloride $(40 \mu \mathrm{L})$, trifluoroethanol $(20 \mu \mathrm{L})$, and heptafluorobutyric anhydride (HFBA, $20 \mu \mathrm{L}$ ) were added to the dried extracts, capped and allowed to equilibrate for 10 minutes. The samples were again evaporated to dryness in a vacuum oven and reconstituted in ethyl acetate $(50 \mu \mathrm{L})$ for analysis using GC/MS.

\section{Analytical Conditions (GC/MS)}

A Shimadzu QP2010 instrument was used for analysis. The column was a RTX-XLB, Ultra low bleed, (Shimadzu Corporation, proprietary phase) $30 \mathrm{~m}$ length $\times 0.25 \mathrm{~mm}$ diameter $\times 0.25 \mu \mathrm{m}$ film thickness. The injection volume was $2 \mu \mathrm{L}$ in splitless mode and the injection temperature was $260^{\circ} \mathrm{C}$. The column flow was $1.3 \mathrm{~mL} / \mathrm{min}$ and the linear velocity $43.3 \mathrm{~cm} / \mathrm{sec}$. The oven was programmed from $130^{\circ} \mathrm{C}$ for $1 \mathrm{~min}$, ramped at $25^{\circ} \mathrm{C} / \mathrm{min}$ to $250^{\circ} \mathrm{C}$, held for $3 \mathrm{~min}$, ramped at $30^{\circ} \mathrm{C} / \mathrm{min}$ to $310^{\circ} \mathrm{C}$. The ion source temperature was $230^{\circ} \mathrm{C}$ and the transfer interface temperature was $250^{\circ} \mathrm{C}$. The instrument was operated in Standard CI mode (positive ion) using methane as the reagent gas. Note: using Shimadzu instrumentation, standard chemical ionization (SCI) is used as terminology for positive chemical ionization mode.

The ions monitored were $307.1,185.1$ for deuterated cocaine (d3); 304.1, 182.1 for cocaine; $375.1,253,1$ for deuterated benzoylecgonine (d3); 372.1, 250.1 for benzoylecgonine. The linearity of the procedure was $0-32$ $\mathrm{ng} / \mathrm{mL}$, and the limit of quantitation was $2 \mathrm{ng} / \mathrm{mL}$ for both cocaine and benzoylecgonine. A sample was not considered positive unless it contained at least $8 \mathrm{ng} / \mathrm{mL}$ of either cocaine or benzoylecgonine. A cumulative positive was not considered valid.

\section{Urine}

The DRI Enzyme Immunoassay Kit for Cocaine Metabolite, Benzoylecgonine (Diagnostic Reagents
Inc., Sunnyvale, $\mathrm{CA}$ ) was used to screen the urine specimens at a cut-off value of $300 \mathrm{ng} / \mathrm{mL}$ according to the manufacturer's package insert. Presumptive positives were re-tested using the Cocaine Metabolite Direct Radioimmunoassay Kit (RIA, Immunalysis, Pomona $\mathrm{CA}$ ). Since both immunoassay kits were specific to benzoylecgonine, a positive result on both was considered valid for the purposes of this study, to report a urine specimen as positive.

\section{Results and discussion}

The hair and oral fluid specimens were considered positive when they were confirmed using GC/MS procedures as described. In the self-reported drug using population, 17 individuals were not positive by any specimen type. Conversely, $7 \%$ of self-reported nonusers were positive in all specimen types. The results are shown in Table I. In previously reported household surveys, under-reporting of recent drug use was noted and was particularly problematic for cocaine and heroin (16). Where possible, in those studies, all three specimens were collected from the subjects. Where multiple samples were collected, oral fluid collection had lower refusal rates than the other matrices (17).

In our study, there were no subjects detected by an oral fluid positive only, from the self-reported users; all positive oral fluid samples had a corresponding urine and/or hair positive specimen. In the self-reported nondrug using subjects, there were no individuals with both positive urine and positive oral fluid who did not have a corresponding positive hair. In fact, there were only two subjects who were positive for drug use (one oral fluid and one urine) who did not have a positive hair test in the non-drug using population. The individual who produced the positive urine had insufficient hair to confirm; the individual with the oral fluid positive (DT0197) also had a hair concentration of $390 \mathrm{pg} / \mathrm{mg}$ of cocaine $70 \mathrm{pg} / \mathrm{mg}$ for benzoylecgonine.

These data indicate that hair, when sufficient specimen is collected for analysis, provides substantially more

Table I : Analytical results from a population admitting cocaine use, and from subjects denying cocaine use.

\begin{tabular}{|l|l|l|l|}
\hline & $\begin{array}{l}\text { Self-reported } \\
\text { Cocaine use }\end{array}$ & $\begin{array}{l}\text { Self-reported } \\
\text { No cocaine use }\end{array}$ & Overall \\
\hline All matrices negative & 17 & 73 & 90 \\
\hline All matrices positive & 52 & 7 & 59 \\
\hline + Hair only & 13 & 12 & 25 \\
\hline + Hair and oral fluid & 5 & 5 & 10 \\
\hline + Hair and urine & 8 & 1 & 9 \\
\hline + Urine only & 2 & 1 & 3 \\
\hline + Oral fluid and urine & 3 & 0 & 3 \\
\hline + Oral fluid only & 0 & 1 & 1 \\
\hline Total & 100 & 100 & 200 \\
\hline
\end{tabular}


information on cocaine use than any other matrix collected in this study. This is in agreement with other publications, indicating hair identifies more positive drug users than the other specimens tested (18).

In total, 90 of the 200 subjects were negative in all sample types, but of the 110 individuals who were positive in at least one matrix, $103(93.6 \%)$ had a positive hair assay, while $67.2 \%$ had positive urinalysis, and $66.3 \%$ a positive oral fluid test. Two hair specimens had insufficient specimen remaining for confirmation. Hair identified $78 \%$ of admitted users. Overall, in the admitted drug using population, the urine detected $65 \%$ of users, oral fluid $60 \%$, although there were a further 11 samples which screened positively but there was insufficient volume to confirm, due to multiple positive screen results.

Among the self-reported non-drug using individuals, the urine was able to identify $9 \%$ of subjects as positive. Oral fluid was better with a $13 \%$ positive detection rate, but hair identified $25 \%$ of individuals who did not admit drug use (Figure 1). Including both populations, the hair identified a higher percentage of cocaine users than oral fluid or urine. Urine and oral fluid gave similar identification rates in the admitted drug using population, with oral fluid higher in those not admitting drug use.

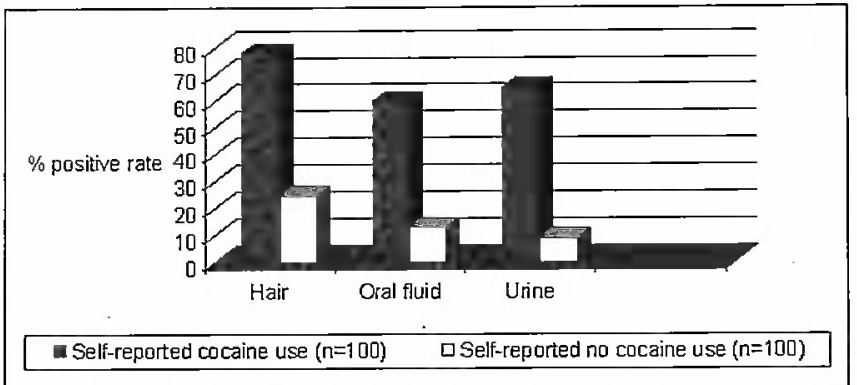

Figure 1 : Percentage of cocaine users identified by each specimen type.

\section{Correlation}

It is difficult to determine whether a correlation exists between the frequency of dose reported by the subjects and the amounts of drug and metabolites detected in the specimens.Variation in the amount of drug, purity of drug, time after sampling, as well as the truthfulness of subjects all affect the outcome. However, within this study group, which was predominantly of chronic users in the self-reported group, it is clear that hair is the best specimen to test in order to identify the highest number of drug users, whether or not self-reported.

\section{Hair Color and Ethnicity}

The hair color and ethnicity of the subjects was recorded at the time of the interview. The state of the art in hair testing is that it is most likely the melanin content of hair which is critical in determining the cocaine content in hair, and not ethnicity. In our subjects, the predominant hair color was black across all ethnic types $(56.1 \%)$. Dark brown and grey accounted for approximately $20 \%$ each of the subjects, with only one subject having blonde hair, and one light brown. Since there was little variation in hair color and melanin content, it was difficult to form any conclusions on the effect of pigmentation on cocaine incorporation. The ethnicity of the subjects also had little effect on the identification of cocaine users. Overall, $40.5 \%$ of all subjects were black, $38 \%$ were white, $11.5 \%$ were Hispanic and $10 \%$ described themselves as "other". Regardless of the ethnic group, hair identified the highest number of positive subjects, followed by similar rates for oral fluid and urine. Blacks accounted for the highest cocaine positivity rates in all specimen types. 63/103 (61.1\%) of the total hair positives identified were from black subjects; $51 / 73(69.8 \%)$ of the oral fluid specimens and 50/74 (67.5\%) of the urine specimens. Whites accounted for $17.4 \%$ of the hair positives, $16.4 \%$ of the positive oral fluid specimens, and $17.5 \%$ of the positive urine samples. This suggests that positive rates, in this particular geographical area, may be related more to drug use patterns, rather than any kind of ethnic or method bias.

\section{Concentrations detected in hair}

The range of concentrations detected in hair was extremely wide (Table II), with both the mean and median values being substantially higher than the proposed cutoffs for regulatory samples. The mean cocaine level is over 100 times higher than the proposed cut-off of 500 $\mathrm{pg} / \mathrm{mg}$. Hair should be less affected by the timing of drug taking, than the other matrices, since the process of incorporation of the drug into the hair occurs over a longer time period than incorporation into urine or oral fluid. The highest cocaine level recorded was over $300,000 \mathrm{pg} / \mathrm{mg}$. The subject, a black female, was 53 years old, and had gray hair. She stated that she used cocaine only once a week. Her hair contained 305, $130 \mathrm{pg} / \mathrm{mg}$ of cocaine, $22,549 \mathrm{pg} / \mathrm{mg}$ of benzoylecgonine and $8,833 \mathrm{pg} / \mathrm{mg}$ of cocaethylene, but did not show the presence of norcocaine. The lowest positive level detected was from the black hair of a white male.

Table II : Concentration of cocaine and its metabolites detected in hair samples $(n=103)$.

\begin{tabular}{|l|l|l|l|l|}
\hline & COC (ng/mg) & BZE (ng/mg) & NC (ng/mg) & CE (ng/mg) \\
\hline Low & 0.51 & 0.054 & 0.059 & 0.058 \\
\hline High & 305.1 & 33.7 & 8.0 & 17.6 \\
\hline Median & 46.6 & 4.5 & 1.4 & 2.0 \\
\hline Mean & 72.7 & 6.9 & 2.0 & 3.8 \\
\hline \% of cocaine & & & & \\
Median & & $\mathbf{9 . 6 \%}$ & $\mathbf{3 . 0 \%}$ & $\mathbf{4 . 3 \%}$ \\
Mean & & $\mathbf{9 . 5 \%}$ & $\mathbf{2 . 7 \%}$ & $\mathbf{5 . 2 \%}$ \\
\hline
\end{tabular}


His hair contained $54 \mathrm{pg} / \mathrm{mg}$ of benzoylecgonine and $509 \mathrm{pg} / \mathrm{mg}$ of cocaine. He did not admit to using cocaine. It is problematic to try to predict any kind of doseresponse correlation due to the difficulties with selfreported drug use behavior.

Overall, benzoylecgonine was present at a median value of $9.6 \%$ of the cocaine concentration. Norcocaine, if present approximated $3 \%$ of the total cocaine, and cocaethylene, if present, accounted for $4.3 \%$ of the cocaine level (Table II).

A chromatogram from a hair specimen testing positively for cocaine, benzoylecgonine, norcocaine and cocaethylene is shown in Figure 2 (DT0011). The system would only allow 6 extracted ion chromatograms to be shown on one page, but the other ions were collected for each sample and used in the determination of positivity according to accepted GC/MS validation protocols.

The hair contained $170 \mathrm{pg} / \mathrm{mg}$ of benzoylecgonine, $1,400 \mathrm{pg} / \mathrm{mg}$ of cocaine, $71 \mathrm{pg} / \mathrm{mg}$ of norcocaine and $58 \mathrm{pg} / \mathrm{mg}$ of cocaethylene. This particular chromatogram was chosen, since it provided analysis of all four drugs at levels which could be seen on one scale. In many subjects, the cocaine level detected was so high that the norcocaine and cocaethylene present would need to be viewed on a separate mathematical scale.

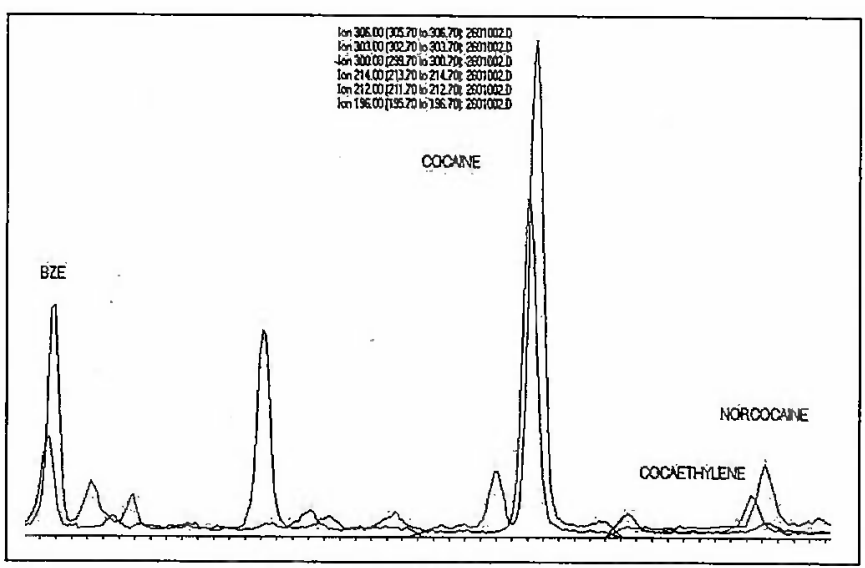

Figure 2 : Ion chromatogram of a positive hair specimen (DT0011).

\section{Concentrations detected in oral fluid}

In 2001, a report comparing saliva testing with urine testing among a criminal justice population was published, concluding that when using urine as the reference standard, the saliva test results indicated a sensitivity of $100 \%$ and a specificity of $99 \%$ for cocaine use (19). Other publications have concluded that urine and oral fluid provide similar positive rates (20) and prevalence information reported in 2005 concluded that in workplace populations, oral fluid and urine gave similar confirmation rates for cocaine metabolites: $1.31 \%$ and $0.93 \%$ respectively. When the standard five drug classes were considered, the confirmation rates for oral fluid and urine were $4.91 \%$ and $4.88 \%$ respectively (21).

In our study, the positive rates for oral fluid and urine were similar in both the admitted drug users and the non-drug using subjects. The range of concentrations measured in oral fluid was from low nanograms per milliliter to over $1000 \mathrm{ng} / \mathrm{mL}$ of both cocaine and benzoylecgonine. Obviously the timing of collection following recent cocaine use is a factor in the level detected. As expected, the highest levels of cocaine were detected in subjects admitting to very recent cocaine use.

The highest recorded oral fluid values for cocaine were over $1000 \mathrm{ng} / \mathrm{mL}$ in three individuals. Two of these subjects admitted using cocaine daily, and one admitted twice a week. As expected, all had used within hours of sample collection and the corresponding hair specimens were also positive.

Figure 3 shows an ion chromatogram of an oral fluid specimen positive for both benzoylecgonine $(13 \mathrm{ng} / \mathrm{mL})$ and cocaine $(4 \mathrm{ng} / \mathrm{mL})$. The subject admitted to using cocaine three times a week and his last intake was at $2 \mathrm{am}$ on the day of collection. The samples were collected in the morning (between 8 and noon), therefore the subject, if truthful in his admission still had parent drug remaining in the oral fluid sample 6-8 hours after ingestion. The urine was also positive, as was his hair, with a cocaine concentration of $162,042 \mathrm{pg} / \mathrm{mg}$ and BZE present at $10,933 \mathrm{pg} / \mathrm{mg}$ $(6.7 \%)$. No norcocaine or cocaethylene was detected.

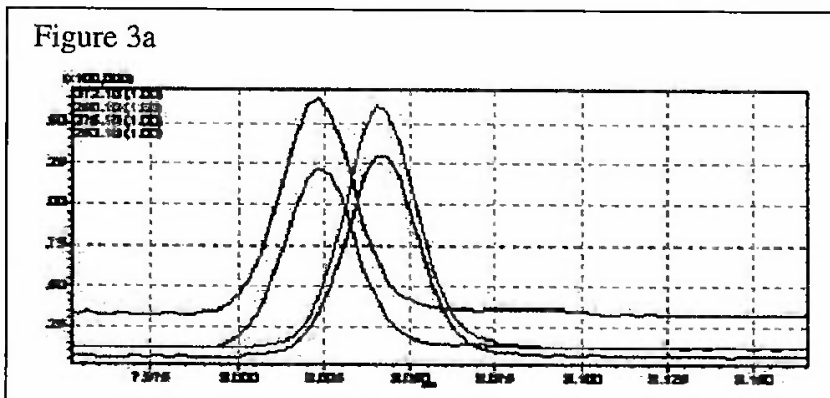

Figure 3b

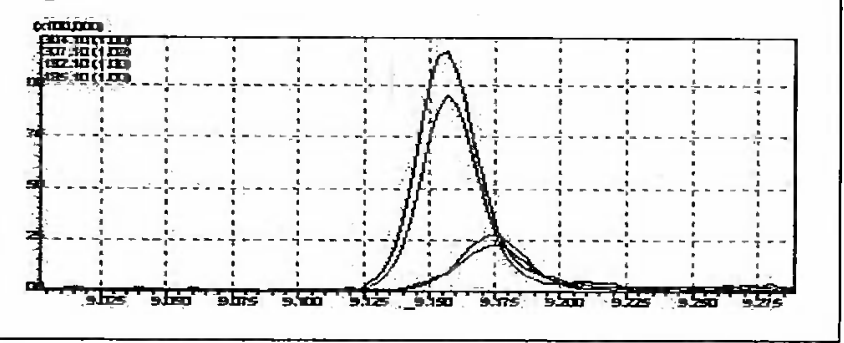

Figure 3 : Extracted ion chromatogram of a positive oral fluid specimen (DT0167)

3a. Benzoylecgonine $13 \mathrm{ng} / \mathrm{mL}$ (Internal standard concentration $16 \mathrm{ng} / \mathrm{mL}$ ) d3-benzoylecgonine: Retention time: 8.02; Ions monitored: 375.1, 253.1

Benzoylecgonine: Retention time: $8.04 \mathrm{~min}$; lons monitored: $372.1,250.1$

3b. Cocaine $4 \mathrm{ng} / \mathrm{mL}$ (Internal standard concentration 16 $\mathrm{ng} / \mathrm{mL}$ ) d3-cocaine: Retention time: $9.15 \mathrm{~min}$; Ions monitored: $307.1,185.1$

Cocaine: Retention time: 9.17 min; Ions monitored: $304.1,182.1$ 


\section{Acknowledgements}

We are grateful to Ms. Toby Evans for facilitating subject access at the Drug and Alcohol Recovery Team (DART) and to Russell Munford (Immunalysis Corporation) for the collection of all the specimens. Many thanks are due to Michelle Nguyen and Erma Abolencia for all the immunoassay testing of oral fluid and hair samples at Immunalysis Corporation. In addition, we thank U.S. Drug Testing Laboratories Inc., Des Plaines, $\mathbb{L}$ for the GC/MS analysis of some oral fluid specimens.

\section{References}

1. Department of Health and Human Services. Substance Abuse and Mental Health Services Administration. Proposed Revisions to Mandatory Guidelines for Federal Workplace Drug testing Programs. Federal Register 69 (71); April 13th (2004).

2. T. Uematsu, A. Mizuno, S. Nagashima, A. Oshima and M. Nakamura. The axial distribution of nicotine content along hair shaft as an indicator of changes in smoking behaviour: Evaluation in a smoking cessation programme with or without the aid of nicotine chewing gum. $\mathrm{Br} \mathrm{J}$ Clin Pharmacol 36: 665-669 (1995).

3. G. Henderson, M. Harkey, C. Zhou, R. Jones and P. Jacob. Incorporation of isotopically labeled cocaine into human hair. I. Dose-response relationships. J Anal Toxicol. 20: 112 (1996).

4. R.E. Joseph, K.M. Hold, D.G. Wilkins, D.E. Rollins and E.J. Cone. Drug testing with alternative matrices II. Mechanisms of cocaine and codeine deposition in hair. $\mathrm{J}$ Anal Toxicol. 23: 396-408 (1999).

5. J.D. Ropero-Miller, B.A. Goldberger, E.J. Cone and R.E. Joseph. The disposition of cocaine and opiate analytes in hair and fingernails of humans following cocaine and codeine administration. J Anal Toxicol. 24: 496-508 (2000).

6. K. Hold, D. Wilkins, D. Rollins, R. Joseph and E. Cone. Simultaneous quantitation of cocaine, opiates and their metabolites in human hair by positive ion chemical ionization gas chromatography-mass spectrometry. J Chromatogr Sci. 36: 125-130 (1998).

7. J.A. Bourland, E.F. Hayes, R.C. Kelly, S.A. Sweeney and M.M. Hatab. Quantitation of cocaine, benzoylecgonine, cocaethylene, methylecgonine, and norcocaine in human hair by positive ion chemical ionization (PICI) gas chromatography-tandem mass spectrometry. J Anal Toxicol. 24(7): 489-495 (2000).

8. M. Rothe and.F. Pragst. Solvent optimization for the direct extraction of opiates from hair samples. J Anal Toxicol. 19(4): 236-240 (1995).

9. F.S. Romolo, M.C. Rotolo, I. Palmi, R. Pacifici and A. Lopez. Optimized conditions for simultaneous determination of opiates, cocaine and benzoylecgonine in hair samples by GC-MS. Forensic Sci Int. 138(1-3): 17-26 (2003).
10. Y. Caplan and B.A. Goldberger. Alternative specimens for workplace drug testing. J Anal Toxicol. 25: 396-399 (2001).

11. N. Samyn, A. Verstraete, C. van Haeren and P. Kintz. Analysis of drugs of abuse in saliva. Forens Sci Rev. 11(1): 1-16 (1999).

12.E.J. Cone, J.M. Oyler and W.D. Darwin. Cocaine disposition in saliva following intravenous, intranasal and smoked administration. J Anal Toxicol. 21: 465-475 (1997).

13. E.T. Moolchan, E.J. Cone, A. Wstadik, M.A. Huestis and K.L. Preston. Cocaine and metabolite elimination patterns in chronic cocaine users during cessation: plasma and saliva analysis. J Anal Toxicol. 24(7): 458-466 (2000).

14. B.D. Paul. Six spectroscopic methods for detection of oxidants in urine: implication in differentiation of normal and adulterated urine. J Anal Toxicol. 28(7): 599-609 (2004).

15. F.M. Urry, G. Komaromy-Hiller, B.Staley, D.K. Crockett, M. Kushnir, G. Nelson and R.E. Struempler. Nitrite adulteration of workplace urine drug-testing specimens. I. Sources and associated concentrations of nitrite in urine and distinction between natural sources and adulteration. J Anal Toxicol. 22(2): 89-95 (1998).

16. M. Fendrich, T.P. Johnson, J.S. Wislar, A. Hubbell and V. Spiehler. The utility of drug testing in epidemiological research: results from a general population survey. Addiction. 99(2):197-208 (2004).

17. M. Fendrich, T.P. Johnson, J.S. Wislar and A. Hubbell. Drug test feasibility in a general population household survey. Drug Alcohol Depend. 73(3):237-250 (2004).

18. T. Mieczkowski, D. Barzelay, B. Gropper and E. Wish. Concordance of three measures of cocaine use in an arrestee population: hair, urine, and self-report. J Psychoactive Drugs. 23(3):241-249 (1991).

19. G. Yacoubian, E.D. Wish and D.M. Perez. A comparison of saliva testing to urinalysis in an arrestee population. J Psychoactive Drugs 33(3):289-94 (2001).

20. G.A. Bennett, E. Davies and P. Thomas. Is oral fluid analysis as accurate as urinalysis in detecting drug use in a treatment setting? Drug Alcohol Depend. 72(3): 265-269 (2003).

21. B. Rowland and L. Presley. Oral fluid and urine statistics: LabOne 2004. Presented at the American Academy of Forensic Sciences Annual Meeting, New Orleans, LA. February 2005 